Discussion Paper No. 11-042

\title{
Understanding the Effects of Violent Video Games on Violent Crime
}
A. Scott Cunningham, Benjamin Engelstätter, and Michael R. Ward

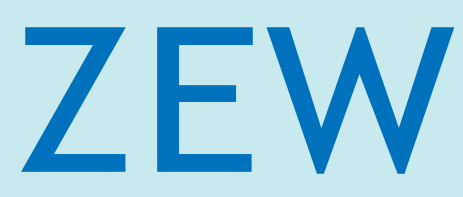

Zentrum für Europäische Wirtschaftsforschung $\mathrm{GmbH}$ Centre for European Economic Research 
Discussion Paper No. 11-042

\title{
Understanding the Effects of Violent Video Games on Violent Crime
}

\author{
A. Scott Cunningham, Benjamin Engelstätter, \\ and Michael R. Ward
}

Download this ZEW Discussion Paper from our ftp server:

http://ftp.zew.de/pub/zew-docs/dp/dp11042.pdf

Die Discussion Papers dienen einer möglichst schnellen Verbreitung von neueren Forschungsarbeiten des ZEW. Die Beiträge liegen in alleiniger Verantwortung der Autoren und stellen nicht notwendigerweise die Meinung des ZEW dar.

Discussion Papers are intended to make results of ZEW research promptly available to other economists in order to encourage discussion and suggestions for revisions. The authors are solely responsible for the contents which do not necessarily represent the opinion of the ZEW. 


\section{Non-technical summary}

Most psychological studies report a positive relationship between violent video game play and aggression. In line with that researchers and policy makers alike understand playing violent video games as contributing factors to increased aggression in teenagers and young adults including, perhaps, high school shootings. However, laboratory studies are unable to account for either the possible selection of relatively violent people into playing violent video games or foregone aggressive effects of alternative activities video game playing may substitute for. Specifically, psychological laboratory experiments cannot address the time use effects of video games which tend to incapacitate gamers from violent activity, e. g. crimes, by drawing them into extended gameplay. Accordingly, laboratory studies may be poor predictors of the net effects of violent video games on society, thus potentially overstating the importance of video game induced aggression. We argue that as both a behavioral tendency toward aggression and incapacitation from aggression are consequences of playing violent video games, the policy relevance of violent video game regulation depends critically on the degree to which one outweighs the other.

We empirically investigate how video games could affect crime using four years of weekly data from the US by matching four different data sources. The number of violent and nonviolent crime incidents each week we obtain from the National Incident Based Reporting System (NIBRS). Our measure for video game play is derived from VGChartz which report the unit sales of the top 50 video games across the US each week. To determine the violent content of each game, we collect information from the Entertainment Software Rating Board (ESRB). This nonprofit body rates the appropriateness of games and provides detailed content descriptions for each game including the degree of violence. To control for unobserved factors that might influence both crime rates and video game play like, e. g., bad weather such as rain or heavy snow, we focus only on changes in game sales associated with differences in game quality as measured by Gamespot, a professional video game rating board (instrumental variable approach).

Our results indicate two opposing effects. They suggest the behavioral effects in line with the psychological studies. If not for the incapacitation effect, violent video games would be associated with more violent crimes. However, the results also support a voluntary incapacitation effect in which playing either violent or non-violent games decrease crimes. Sales of either violent or non-violent games are associated with decreased violent and non-violent crime. The incapacitation effect dominates the behavioral effect such that, overall, violent video games lead to decreases in violent crime. 


\section{Das Wichtigste in Kürze}

Viele psychologische Studien berichten von einem positiven Zusammenhang zwischen dem Spielen von Videospielen mit Gewaltinhalten und Aggression. Folglich verstehen sowohl Forscher als auch politische Entscheidungsträger das Spielen eben dieser gewalthaltigen Videospiele als einen unterstützenden Faktor für aggressives Verhalten von Teenagern und jungen Erwachsenen und, möglicherweise, auch als Erklärung für Amokläufe an Schulen. Allerdings berücksichtigen Laborexperimente nicht, dass vergleichsweise gewaltbereite Personen mit höherer Wahrscheinlichkeit Videospiele mit Gewaltinhalten spielen (Selbstselektion). Außerdem können derartige Experimente aggressive Auswirkungen von Tätigkeiten, die alternativ durch Videospielen ersetzt werden könnten, nicht abbilden, d. h. psychologische Laborexperimente berücksichtigen nicht, dass Videospiele ihre Spieler daran hindern, andere, potentiell gewaltsame Tätigkeiten, wie beispielsweise Verbrechen, auszuüben. Entsprechend könnten derartige Experimente den Nettoeffekt von Videospielen auf die Gesellschaft nur unzureichend vorhersagen und den Einfluss von aggressivem Verhalten aufgrund des Konsums von Spielen mit Gewaltinhalten überschätzen. Wir argumentieren, dass die Auswirkungen des Spielens derartiger Videospielen sowohl die Förderung von aggressivem Verhalten als auch die zeitliche Einschränkung für die Ausübung aggressiver Tätigkeiten umfassen. Die politische Relevanz einer Regulierung von gewalthaltigen Videospielen hängt entscheidend davon ab, inwieweit der eine Effekt den anderen übersteigt.

Empirisch prüfen wir die Auswirkungen von Videospielen auf die Kriminalität mit einem amerikanischen Datensatz, der sich aus vier unterschiedlichen Datenquellen zusammensetzt und vier Jahre wöchentlicher Beobachtungen liefert. Die Anzahl gewalttätiger Verbrechen und Verbrechen ohne Gewalteinwirkung pro Woche liefert der Datensatz des National Incident Based Reporting Systems (NIBRS). Unser Maß für die Nutzung von Videospielen erhalten wir von VGChartz, einer Website, welche die wöchentlichen Einheitenverkäufe der Top 50 Videospiele innerhalb der Vereinigten Staaten ausweist. Um den Gewaltinhalt der Spiele zu messen, nutzen wir Informationen des Entertainment Software Rating Boards (ESRB), einer gemeinnützigen Institution, welche die Alterseignung der Videospiele bestimmt und neben anderem Inhalt auch den Grad an Gewalt im Spiel beschreibt. Um unbeobachtbare Faktoren zu berücksichtigen, die sowohl die Nutzung von Videospielen als auch die Kriminalitätsrate beeinflussen könnten, wie beispielsweise schlechtes Wetter mit starkem Regen oder Schnee, fokussieren wir uns ausschließlich auf Veränderungen in den Verkaufszahlen von Videospielen, die mit unterschiedlichen Qualitätsbewertungen der Spiele zusammenhängen (Instrumentvariablenansatz). Die Qualitätsbewertungen der Spiele in unserem Datensatz beziehen wir dabei von Gamespot, einem professionellen Gremium zur Bewertung von Videospielen.

Unsere Ergebnisse zeigen zwei gegensätzliche Effekte. Sie weisen, im Einklang mit den psychologischen Studien, auf Verhaltensänderungen in Form von erhöhter Aggressivität hin. Ohne 
einen zeitlich einschränkenden Effekt wären gewalthaltige Videospielen verbunden mit einem Anstieg der Zahl an Gewaltverbrechen. Allerdings zeigen unsere Ergebnisse indes auch jenen zeitlichen Effekt, der auffängt, dass Spieler freiwillig ihre verfügbare Zeit zum Spielen aufwenden, was die Kriminalität verringert. So führen Verkäufe sowohl gewalthaltiger als auch gewaltfreier Spiele zu einem Rückgang von gewaltlosen und Gewaltverbrechen. Dieser zeitbeschränkende Effekt dominiert dabei den durch Verhaltensänderungen bedingten Effekt. Insgesamt führen folglich Videospiele mit Gewaltinhalten zu Rückgängen in der Zahl der Gewaltverbrechen. 
"Understanding the Effects of Violent Video Games on Violent Crime”

A. Scott Cunningham, Baylor University

Benjamin Engelstätter, ZEW Mannheim

Michael R. Ward, University of Texas at Arlington

April, 2011

\begin{abstract}
Psychological studies invariably find a positive relationship between violent video game play and aggression. However, these studies cannot account for either aggressive effects of alternative activities video game playing substitutes for or the possible selection of relatively violent people into playing violent video games. That is, they lack external validity. We investigate the relationship between the prevalence of violent video games and violent crimes. Our results are consistent with two opposing effects. First, they support the behavioral effects as in the psychological studies. Second, they suggest a larger voluntary incapacitation effect in which playing either violent or non-violent games decrease crimes. Overall, violent video games lead to decreases in violent crime.
\end{abstract}

JEL Codes: D08, K14, L86

Keywords: Video Games, Violence, Crime 


\section{Introduction}

From the sensational crime stories of the $19^{\text {th }}$ century (Comstock and Buckly 1883), to the garish comic books of the early $20^{\text {th }}$ century, (Hadju 2009), to today's violent video games, Americans have made efforts to reduce children's access to violent media because of concerns over their social costs. These concerns may not be unfounded as numerous studies purport to find that violent media of all sorts, including games, can cause increases in measured aggression. Aided in part by mounting evidence that violent video game play cause aggression, states have passed legislation criminalizing the distribution of violent video games to minors. ${ }^{1}$

The research is not clear on how large the increase in aggression caused by these games. Craig Anderson, a long-time researcher in the effect of violent media on aggression has contended that "one possible contributing factor [to the Columbine High School killings was the shooters' habits of playing] violent video games. [The shooters] enjoyed playing the bloody shoot-`em-up video game Doom, a game licensed by the U.S. Army to train soldiers to effectively kill" (quoted in Kutner and Olson 2009). ${ }^{2}$

If violent video games can be shown to cause violence, then laws aimed at reducing access may benefit society at large. Yet to date, though there is ample evidence that violent video games cause aggression in a laboratory setting, laboratory stings cannot address selection or incapacitation. Ward (2010) shows that adolescents who are otherwise predisposed to violence tend to select into video game play. Likewise, since the hours it takes to "beat the game" substitute for some other activity, a complete analysis must consider the

\footnotetext{
${ }^{1}$ In 2010, California passed a law making it a punishable offense for a distributor to sell a banned violent video to a minor. The case is currently before the US Supreme Court.

${ }^{2}$ In the opening paragraph of his literature review, Anderson (2004) suggested violent video games were responsible for the recent wave of school shootings since the late 1990s.
} 
opportunity cost of this time. Violence may fall because gamers engaged in virtual violence are not simultaneously engaged in actual violence.

To date, there is no evidence that violent video games cause violence or crime. In fact, two recently published studies analyzed the effect of violent media (movies and video game stores) on crime, and found increased exposure may have caused crime rates to decrease (Dahl and Dellavegna 2009; Ward 2011). These studies, unlike the laboratory studies, were conducted with observational data, which poses unique scientific challenge to establishing causality. However, since laboratory studies have never shown that video game violence causes crime or violence, despite researchers out-of-sample predictions (Anderson 2004), observational studies may be the only ethical and practical way to test for such a causal effect.

To many in this field, it is logical to assume that if exposure to violent media causes aggression in the lab, that it will therefore cause aggression when exposure occurs nonrandomly outside the laboratory, including other outcomes associated with aggression, such as crime and violence. In this paper, we argue that since laboratory experiments have not examined the time use effects of video games, which incapacitate violent activity by drawing individual gamers into extended gameplay, laboratory studies may be poor predictors of the net effects of violent video games in society. Consequently, they overstate the importance of video game induced aggression as a social cost. We argue that since both aggression and time use are a consequence of playing violent video games, then the policy relevance of violent video game regulation depends critically on the degree to which the one outweighs the other. If, as we find in our study, the time use effect of violent video games reduce crime by more than the aggression effects increase it, then the case for regulatory intervention becomes weaker. While some early work has been done on the long-term effects of video game play, 
nearly all the laboratory evidence that currently exists has only uncovered very short-term effects, which is when time use effects could be the most important. ${ }^{3}$

As with Dahl and Dellavegna (2009) and Ward (2011), we use a proxy for individuals' exposure to violent video games - the volume of sales of violent video games in a week among the top 50 best-selling video games from 2005-2008 - and relate it to a marker for violent behaviors - weekly aggregate violent crime incidents from the National Incident Based Reporting System (NIBRS). Using time series modeling, as well as an instrumental variables approach, we estimate the effect of an increased volume of violent video game sales over the period on the number of criminal incidents recorded to law enforcement at the weekly level and find that increased violent video games are associated with decreases in crime rates, similar to Dahl and Dellavegna (2009) and Ward (2011).

One advantage of our approach is that we can attempt to disentangle the separate effects of both a behavioral change toward more aggression and incapacitation due to time use. Our results provide some support for the psychological finding that, absent incapacitation, violent video games lead to more violent crimes. However, our results also indicate this is dominated by an incapacitation effect leading to a net reduction in violent crimes. This approach can help guide investigators into the design of more holistic research designs, such as field experimentation and other quasi-experimental methodologies, to determine whether the net social costs of violent games are non-trivial. The shortcoming of our approach is due to the limitations of our data on game sales. Unfortunately, the industry does not report cross-sectional variation in game sales - only the national weekly sales of the top 50 highest grossing games are available. As a result, our paper follows a methodology

\footnotetext{
${ }^{3}$ In Anderson (2004), the author notes the glaring omission of longitudinal studies of effects of violent video games on aggression in his conclusions on the state of the research, calling for more studies aimed at investigating the long-term effects. If nothing else, though, this makes our point that the abundance of evidence that we know does exist only speaks to short-term effects of violent video games on aggression, which is the purpose of this study here.
} 
similar to Dahl and Dellavegna (2009), who estimated the impact of violent movies, proxied by daily ticket sales, on crime using only time series methods.

The paper is structured as follows: the second section presents our theoretical modeling of the effect of violent video games on crime based on the general aggression model (GAM) using Becker and Murphy's theory of addiction and Becker's theory time use. The third section presents our data and methodology. The forth presents and discusses our results. We conclude with a brief discussion of the implications for public policy.

\section{Theory of Violent Video Games Effect on Crime}

To make the theoretical concerns more transparent, we present versions of both the leading psychological theory of violent video games' effect on aggression, as well as canonical economic models that can incorporate psychological insights, to illustrate how violent video game play can have ambiguous effects on crime and severe aggression despite a positive effect on the aggressive tendencies of a person. We modify the Becker and Murphy (1988) addition model to a video game setting to get a version of a general aggression model (GAM). At the same time, a common observation is that new releases of popular video games often results in long hours of play by gamers. We apply the time allocation model of Becker (1965) to the video game setting to show that the resultant 'voluntary incapacitation' could reduce violent outcomes.

\section{A. Incorporating GAM into a Rational Addiction Model}

Though the empirical foundation of a causal effect of violent video games on aggression has been carefully documented in decades of experimental work, socialpsychological theories explaining this empirical relationship is relatively new. Bushman and Anderson (2002) and Anderson and Bushman (2002) present a psychological theory of such a link that they call the general aggression model, or GAM. GAM hypothesizes that violent 
media, including violent video games, increases a person's aggressive tendencies through a process of social learning that occurs simultaneous to the exposure itself. Violent media causes the person to mistakenly develop certain scripts, or rules of thumb, that are used to interpret social situations both before they occur, as well as afterwards. GAM posits, in other words, that violent video games cause aggression by biasing individuals towards forming incorrect beliefs about relative danger that they are in. Perception biases towards hostility, therefore, can in turn cause the person to respond in either a "fight or flight" fashion. It may also permanently alter a person's point of view, creating an aggressive personality as an outcome (Bushman and Anderson 2002).

The GAM is, in many ways, a description of a person's own production function in which time inputs are mixed with virtual media to produce thoughts and sensations. The accidental byproduct of this production, though, is that the exposure may also modify the person's future capital stock for producing aggression such that current consumption can change the future productivity of aggression.

The "rational addiction" model (Becker and Murphy 1988) encompasses behaviors that may not meet a psychological definition of addiction. The key insight for GAM is that consumption of a good in one period not only affects current utility directly and, through a capital stock accumulation mechanism, but also affects future utility indirectly. For example, drinking alcohol today builds up one's tolerance for alcohol (desensitization) that is modeled as a stock variable that increases the marginal utility. Hence, current consumption increases the agent's optimal level of future alcohol consumption. In our context, we do not model video game play as addictive itself, but rather we consider that violent video game play could affect future utility from aggressive behaviors.

The model primitives include per period utility: 


$$
U\left(V_{t}, A_{t}, X_{t} ; S_{t-1}\right)
$$

where $V$ is video game play, $A$ is aggressive activities, $X$ is all other goods and $S$ is the stock of aggressive tendencies. The stock, $S_{t}$, has initial value $S_{0}$ but it increases with continued violent video game play following the law of motion, $S_{t}=(1-\rho) S_{t-1}+\delta V_{t}$. Psychological models of desensitization suggest that $\sigma, \delta>0$ so that current consumption affects the rate at which this stock changes. This law of motion implies that:

$$
S_{t}=(1-\rho)^{t} S_{0}+\delta \sum_{\tau=0}^{t-1}(1-\rho)^{t-\tau-1} V_{\tau}
$$

We assume that a larger stock of aggressiveness increases the marginal utility from aggression in any period, i.e. $\partial^{2} U / \partial A \partial S_{t-1}>0$. To isolate this effect, utility is separable over time and across most goods within a period. The exception we focus on is the stock of aggressiveness, a product of past violent video game playing, affects the marginal utility from aggression. This is done by assuming a Cobb-Douglas utility with constant marginal utility except for terms involving aggression:

$$
U\left(V_{t}, A_{t}, X_{t} ; S_{t}\right)=\alpha^{V} \ln \left(V_{t}\right)+\alpha^{A} S_{t-1} \ln \left(A_{t}\right)+\alpha^{X} \ln \left(X_{t}\right)
$$

For a lifetime with $T$ periods, lifetime utility is given by:

$$
\sum_{t}^{T} \beta^{t}\left(\alpha^{V} \ln \left(V_{t}\right)+\alpha^{A} S_{t-1} \ln \left(A_{t}\right)+\alpha^{X} \ln \left(X_{t}\right)\right)
$$

or

$$
\sum_{t}^{T} \beta^{t}\left(\alpha^{V} \ln \left(V_{t}\right)+\alpha^{A}\left((1-\rho)^{t} S_{0}+\delta \sum_{\tau=0}^{t-1}(1-\rho)^{t-\tau-1} V_{\tau}\right) \ln \left(A_{t}\right)+\alpha^{X} \ln \left(X_{t}\right)\right)
$$

The lifetime budget constraint with wealth $W$ is: 


$$
\sum_{t}^{T} \beta^{t}\left(p_{t}^{V} V_{t}+p_{t}^{A} A_{t}+p_{t}^{X} X_{t}\right)-W=0
$$

Consistent with Becker and Murphy (1988), consumers are forward looking as to the effect of video games on future aggression. Let $\lambda$ be the Lagrange multiplier on the wealth constraint. They maximize lifetime utility with respect to video game play and aggression in each period subject to their wealth constraint. This yields $3 T$ first-order conditions and $3 T$ unknowns. The first-order condition for video game play in period $t$ is:

$$
\frac{\alpha^{V}}{V_{t}}+\alpha^{A} \delta \sum_{\tau=1}^{T} \beta^{\tau+1}(1-\rho)^{\tau} \ln \left(A_{t+\tau}\right)=\lambda p_{t}^{V} .
$$

The first term on the left represents the direct effect of video game play on current period utility while the second represents an indirect effect of current video game play on utility in all subsequent periods through its effect on the marginal utility from aggression. Agents consider both effects when they respond to an exogenous shock to video game prices. All else equal, a relatively lower current price of video games will imply relatively more current period video game play. In the empirical model below, we identify a price reduction with an exogenous increase in the quality of games.

The first-order condition for aggression in period $t$ is:

$$
\frac{\alpha^{A}}{A_{t}}\left((1-\rho)^{t} S_{0}+\delta \sum_{\tau=0}^{t-1}(1-\rho)^{t-\tau-1} V_{\tau}\right)=\lambda p_{t}^{A}
$$

This implies that agents choose to be more aggressive when their current stocks of aggressive tendencies are higher. These stocks will be higher if they have recently consumed relatively more video games because of relatively lower recent video game prices (or higher video game quality). Thus, the dynamics are as follows. Even forward looking agents respond to temporarily low video game prices with temporarily more video game play. This results in a 
temporary increase in the stock of aggressive tendencies in subsequent periods and, thus, a temporary increase in aggressive behaviors in subsequent periods.

While the model predicts specific inter-temporal linkages, it is silent on how long the time horizon would be for an aggressive response to an exogenous increase in video game play. Depending on how fast the stock parameter depreciates, the value of $\rho$, it might be that the aggression rises and falls over days, weeks or even years. To date the psychological literature studying the impact of violent video games on aggression has focused primarily on short-run, intra-day, responses as opposed to longitudinal outcomes (Anderson 2004). In our empirical analysis below, we can only test over a few weeks' time. However, we note that we are unaware of any empirical studies linking media violence to aggressive behavior more than a few weeks later. ${ }^{4}$

\section{B. Incorporating Violent Video Game Effects into a Time Use Model}

The opportunity cost of playing a video game is not just pecuniary but also includes lost time. In fact, for many gamers, the value of the time spent playing a game may be worth much more than the pecuniary cost of the game. This time spent gaming cannot be spent on other activities, both legitimate activities and illicit violent activities, if time use is rival in consumption. Evidence for video game having a time use component can be found in Stinebrickner and Stinebrickner (2008). The authors identified a causal effect of studying on academic performance by utilizing the random assignment of college students to roommates with a video game console, relative to the counterfactual, which caused students to study less often, and in turn, to perform worse in school.

Even if a gamer is predisposed to being more aggressive due to gaming, he can express this aggression only over a shorter time non-gaming period. In contrast to the

\footnotetext{
${ }^{4}$ Ward (2011) does relate yearly variation in video game demand to annual changes in crimes and deaths.
} 
heightened aggressive tendencies described in our modified GAM-addiction model, 'voluntary incapacitation' of the gamer while gaming would tend to reduce aggressive outcomes, without necessarily a reduction in long-term aggressive tendencies.

To see this, we develop a simple model of time allocation (Becker (1965). Consider a single period model in which agents get utility from playing video games, from acts of aggression, and from all other goods, $\mathrm{U}(V, A, X)$. Consumption of one unit of any good involves both pecuniary and time costs. For simplicity assume a linear consumption technology in which consumption of one unit of good $i$ entails a pecuniary price $p_{i}$ and a time cost $r_{i}$. In addition, the agent can convert time into income by working $h$ hours at wage $w$. Now agents face two constraints:

$$
\begin{gathered}
p_{V} V+p_{A} A+p_{X} X=h w \\
r_{V} V+r_{A} A+r_{X} X=T-h .
\end{gathered}
$$

These two conditions can be combined through $h$ to yield:

$$
\left(p_{V}+w r_{V}\right) V+\left(p_{A}+w r_{A}\right) A+\left(p_{A}+w r_{X}\right) X=w T
$$

Let $\lambda$ be the Lagrange multiplier for this constraint. Optimality is determined from the firstorder conditions for utility maximization:

$$
\begin{aligned}
& \frac{\partial U(V, A, X)}{\partial V}=\lambda\left(p_{V}+w r_{V}\right) \\
& \frac{\partial U(V, A, X)}{\partial A}=\lambda\left(p_{A}+w r_{A}\right) \\
& \frac{\partial U(V, A, X)}{\partial X}=\lambda\left(p_{X}+w r_{X}\right)
\end{aligned}
$$

For standard utility functions, these four equations and four unknowns yield a unique interior solution. One implication is that consumption of a good depends on the 'full' price i.e., video game demand depends on $p_{V}+\mathrm{w} r_{V}$. A reduction in the pecuniary price of video games, $p_{V}$, will lead to an increase in consumption of video games. However, this increase in video game 
play entails both pecuniary and time costs. It could be that video game play does not affect the marginal utility from aggression, or indeed it may augment it, i.e., $\partial^{2} \mathrm{U} / \partial \mathrm{A} \partial \mathrm{X}>0$. However, if the ratio time costs to pecuniary costs of video games, $r_{V} / p_{V}$, is relatively large, the consumer will tend to substitute away from other activities with relatively high time to pecuniary cost ratios. Committing acts of aggression tend to fit this description.

\section{Data and Methodology}

Randomized assignment of a treatment with comparison groups used to make comparative counterfactuals is widely considered the "gold standard" in the social sciences (Fisher 1935; Campbell and Stanley 1963; Rosenbaum 2002). Yet, it is widely known that experimentalism may fail to identify true causal effects for a variety of reasons (Berk 2005; Deaton, 2010; Heckman and Urzua, 2010; Imbens 2010). While others have noted the failure of researchers in this literature to satisfy the rigorous conditions for establishing causality (Ferguson and Kilburn 2008; Olson and Kuttner 2009) our article will focus on a separate statistical challenge not mentioned in these earlier studies: the challenge of internal versus external validity.

Finding of a positive effect of violent games on aggression does not therefore mean that violent video games played will cause crime if the incapacitation effects from time use swamp the marginal increase in aggression in the person. By design, laboratory studies - both by ignoring alternative time use and by treating both treatment and control groups with this separate effect - cannot be used to guide researchers as to what expect outside the lab. In this sense, the studies have internal, but may not have external validity on the incidence of socially costly aggression from violent video game play (Campbell and Stanley 1963). Quasi- 
experimental methods, such as panel econometric methods, regression discontinuity and instrumental variables, as well as field experimentation (Harrison and List 2004; Angrist 2006) may be more suitable estimating the social costs of violent video games since they allow for the estimation of all known and unknown theoretical mechanisms. In this section, we explain our research design and the data used to overcome some of the limitations of a purely experimental methodology.

\section{A. Empirical Methodology}

These models of video game violence suggest that the effect of violent video game play on crime will depend on whether a sizable stock of aggressive tendencies accumulates and on the games' time use intensities. On the one hand, violent games that raised the players' stock of aggression would cause crime rates to be increasing in the amount of violent video games played, depending on the rate at which that stock eroded during nonuse. But because games can be thought of as a kind of entertainment commodity that the agent consumes through time usage, even violent games might decrease crime if voluntary incapacitation due to game play crowds out time spent engaging in activities that lead to criminal acts.

Given that the theoretical predictions are ambiguous, the policy relevance of the laboratory studies is unclear, suggesting that more empirical work outside of a laboratory context is warranted. However, without experimental data, causal inference is problematic. Correlations between video game play and crime may or may not reflect a causal relationship if the unobserved determinants of crime are correlated with video game play. For instance, bad weather such as rain or heavy snow which causes individuals to remain at home would both increase the likelihood of playing video games and decrease the returns to crime through 
higher chances of finding a resident at home. ${ }^{5}$ Hence, negative correlations between crime and violent video game play could purely be a consequence of omitted variable bias.

One solution to omitted variable bias when there is time-variant heterogeneity is to employ instrumental variables (IVs) assuming the researcher has an instrument that is strongly correlated with individual game play but uncorrelated with the determinants of crime. This approach exploits exogenous variation in video game play that is not due merely to changes in the determinants of crime providing greater assurance that the estimated effect is causal. We use the ratings of video games by a video games rating agency as IVs. Our IV strategy exploits the variation in game sales correlated only with the variation in quality, and thus is mostly free of variation due to factors related to crime.

Zhu and Zhang (2010) show that consumer reviews of video games are positively related to game sales. Ratings are valuable pieces of information for video games because games are complex experience goods for which gamers cannot know their preferences without playing. Our data on professional ratings contain rich information that communicates the kinds of information that gamers value in forecasting their beliefs about the game, and as beliefs and anticipation are drivers of the game sales, we would expect these rating institutions to play important roles in forming consumer prior beliefs about the game and therefore their purchases. But we also have some evidence from other industries that would suggest scores would independently cause purchases to rise, independent of the unobserved factors that cause expert opinion and purchases to be highly correlated. Reinstein and Snyder (2005) used exogenous variation in Siskel and Ebert ratings due to disruptions in their pair's reviewing to determine a causal effect on movie demand. More recently, Hilger Rafert and Villas-Boas (2010) found that randomly assigned expert scores on bottles of wine in a retail

\footnotetext{
${ }^{5}$ While the example is a valid concern for measures of video game play, it may be less problematic for this study given that we do not use high frequency game play as a measure of violent video game consumption. Rather, we use sales in a week, which mitigates some of the concerns over weather given that it is the cumulative sales of games that determines our measure of consumption, which should be relatively insensitive to changing weather conditions on a given day.
} 
grocery store caused an increase in sales for the higher rated, but less expensive, wines. While these studies do not confirm that there are exogenous forces in video game ratings that drive consumer purchases, they are suggestive.

We begin by estimating a standard multivariate regression model of the incidence of various crimes as functions of, among other controls, the prevalence of non-violent and violent video games. Our outcome variable of interest, $C_{t}$, is the number of new and reported criminal incidents in week $t$. While the dataset we use documents criminal offenses on a daily basis, since the video game sales data are available only on a weekly basis, we aggregate crimes into weekly measures to focus on same-week exposure. Accordingly, we employ a simple least squares estimator so as to more easily instrument for video game exposure. ${ }^{6}$

Our main explanatory variables are aggregated current and lagged values of weekly sales volumes for both non-violent and violent video games. Video games appear to depreciate quickly. This may be because new games are played intensively for a few weeks after purchase and are not replaced with a new game until after some diminishing returns have been reached, or it may suggest that firms typically stagger the release dates of games. We measure the cumulative effect of games with the sales volume of the current week's sales along with the various lags of previous weeks' sales so as to capture the effect of higher volume of gameplay with unknown time to triggered crime. Following the models developed in section 2 the benchmark specification is:

$$
\ln \left(C_{t}\right)=\beta_{\text {niv }} \ln \left(V G_{t}^{n i v}\right)+\beta_{i v} \ln \left(V G_{t}^{i v}\right)+\beta_{t} \text { trend }_{t}+\beta_{m} \text { month }_{t}+\varepsilon_{t}
$$

The number of crime incidents depends on the exposure to intensive violent video games $V G_{t}^{i v}$ and not intensively violent games $V G_{t}^{\text {niv }}$. The coefficient $\beta_{i v}$ can be interpreted as the percent increase in crime incidents for each percent increase in intensively violent video games sold in week $t$. $\beta_{\text {niv }}$ can be interpreted accordingly covering the impact of not

\footnotetext{
${ }^{6}$ Our empirical methodology is in large part based on Dellavegna and Dahl's (2008) study of the effect of movie violence on crime.
} 
intensively violent video games. The identification of the parameters is based on the timeseries variation in the style of violence in the video games. Comparing the estimates of $\beta_{i v}$ and $\beta_{\text {niv }}$ a difference-in-difference estimate of the effect of intensely violent video games versus not intensely violent games can be achieved. The benchmark specification contains additionally seasonal controls in form of dummy variables for months and a time trend to account for a general decline in crimes over time.

The measured effect from this specification can represent a confluence of many effects. It is possible for there to be a positive behavioral effect, as found in the laboratory, and a negative voluntary incapacitation effect. This specification could only measure the net effect. It may be possible to disentangle the behavioral effects from the incapacitation effect by addressing whether the mix of crimes becomes more or less violent as a result of violent video game exposure. Using the FBI's classification of crimes as violent or non-violent, we estimate:

$$
\ln \left(V C_{t} / C_{t}\right)=\gamma_{n i v} \ln \left(V G_{t}^{n i v}\right)+\gamma_{i v} \ln \left(V G_{t}^{i v}\right)+\gamma_{t} \text { trend }_{t}+\gamma_{m} \text { month }_{t}+v_{t}
$$

where $V C_{t}$ is the number of violent crimes. This specification measures whether violent and non-violent video game play has a larger effect on violent or non-violent crimes. A positive estimated value of $\gamma_{i v}$ would indicate that the violent video games have a positive effect on violent crimes relative to all crimes. Under the assumption that incapacitation results equally for violent and non-violent crimes, this would indicate that violent video games induce behaviors toward violent crimes.

Besides the benchmark specification we employ two additional specifications as robustness checks. The specifications cover specific segments of the population we expect to be more frequent gamers, e.g. people aged between 15 and 30 years and high school and college students. For each crime incident, NIRBS provides information on the age of the offender and on the location of the incident. In the first robustness check, we select our sample for offenders aged between 15 and 30 years and compare these results to the results 
obtained from the sample of offenders who are 35 to 50 years old. In our second check, we extend our estimation procedure to compare the effects on the number of incidents reported on school campuses to the number committed at other locations.

\section{B. Video Game Sales Data}

Our treatment variables for video game play are derived from video game unit sales volume data from VGChartz ${ }^{7}$. Beginning consistently in 2005, this site has provided unit sales volume information for each of the top 50 selling video console games each week. Sales volumes are reported for several geographical areas including worldwide reports and amounts for specific countries like USA, Japan, Europe, Middle East, Africa or Asia. In addition, VGChartz provides information about the publisher and the console for each game. In our sample period 2005 to 2008 the VGChartz dataset contains 1,091 different titles over the 208 weeks for the US with some of these titles being the same game for different gaming consoles. In sum, the games are provided from 47 different publishers and designed for nine different gaming consoles. While VGChartz includes the top 50 selling games each week, it only covers a portion of all sales in the US video game market. A game's week of release is almost always its top selling week. Figure 1 indicates that most games stay in the top 50 for only a few weeks. Moreover, as Figure 2 indicates, the top selling games sell much more than even the lower ranked top 50 games. These features suggest that there is considerable weekto-week variation in the games, and the types of games, being played. According to the Entertainment Software Association (ESA) ${ }^{8}$ VGChartz account for about one-quarter of the 2005 units (ESA Annual Report, 2010). This fraction rises to almost one-half in 2008.

Our measure of violent videogame content stems from the Entertainment Software Rating Board (ESRB). ${ }^{9}$ This non-profit body independently assigns a technical rating (E, E10, $\mathrm{T}, \mathrm{M}$, and A) which defines the audience the game is appropriate for where E classifies games

\footnotetext{
${ }^{7}$ http://www.vgchartz.com/

${ }^{8} \mathrm{http}: / /$ www.theesa.com - The reported numbers from ESA also include games for personal computers which amount to about 10 percent of the market each year and are intentionally not included in VGChartz.

${ }^{9}$ http://www.esrb.org
} 
for everybody, E10 for everyone aged 10 and up, T for teens, M games for a mature audience, and A for adult content. In addition, ESRB provides detailed description of the content in each game on which the rating was made, including the style of violence, e. g. language, violence, or adult themes. For all of the 1,091 titles in our sample we collected the appropriate ESRBrating and all content descriptors. Based on this content information we identify 762 nonviolent and 329 violent games, of which 105 titles are described as intensely violent. Almost all violent games are mostly rated T or $\mathrm{M}$. All intensely violent games are rated M. Merging both data sources together we can construct measures of the aggregate unit sales of nonviolent, violent, and intensely violent video games for each week. The weekly sales are pictured in Figure 3 for all games and intensely violent games. Overall, the two graphs follow a similar pattern with a peak around the Christmas gift purchasing period. In the mid of 2008, however, the intense violent games seem to account for almost all sales of the violent games. As argued in section 2, the prevalence of video games in a week is not randomly distributed over the sample and therefore may be endogenous. For instance, if changing economic conditions caused unemployment to rise, and in turn crime rates, as well as caused leisure activities like video games to rise, then we might observe positive correlations between video game play and crime that is driven purely by these changing economic factors (Raphael and Winter-Ebmer 2001; Gould, Weinberg and Mustard 2002). We address the potential endogeneity of video games with instrumental variables using expert review of each title as an instrument for purchases.

Our expert review data comes from the GameSpot website. ${ }^{10}$ GameSpot provides news, reviews, previews, downloads and other information for video games. Launched in May 1996 GameSpot's main page has links to the latest news, reviews, previews and portals for all current platforms. It also includes a list of the most popular games on the site and a search engine for users to track down games of interest. The GameSpot staff reviewed almost

\footnotetext{
${ }^{10} \mathrm{http}: / / w w w . g a m e s p o t . c o m$
} 
every game in our sample and rated the quality of the titles on a scale from 1 to 10 with 10 being the best possible rank. These so called GameSpot-scores assigned to each game are intended to provide an at-a-glance sense of the overall quality of the game. The overall rating we employ is based on evaluations of graphics, sound, gameplay, replay value and reviewer's tilt. A possible issue with this measure is that GameSpot changed the rating system in mid of 2007 to employ guidelines and a philosophy focusing more on a prospective customer rather than a hardcore-fan that the reviewers had focused on before. Nevertheless, the five mentioned aspects are essential parts of a game that are still reviewed in detail by a GameSpot reviewer but will not get an own rating score anymore. We do not consider this change in the GameSpot focus to noticeably affect the overall GameSpot-score.

We expect the quality rating of the games to be positively correlated with their sales as better-rated games usually are more highly demanded. It is possible that some games have the opposite relationship if they are based on a popular tie-in from a movie, e. g. Harry Potter, or sequels, e. g. the Final Fantasy series. Developers know that these games will sell well due to their popular tie-in which may lower the returns to investment in game quality. However, in table 2 we show that, a game title's weekly sales are positively related to the Game Spot score for games of different violence profiles.

\section{Crime Data}

For our measure of weekly crime, we used the National Incident Based Reporting System, or NIBRS. NIBRS is a federal data collection program begun by the Bureau of Justice Statistics in 1991 for gathering and distributing detailed information on criminal incidents for participating jurisdictions and agencies. Participating agencies and states submit detailed information about criminal incidents not contained in other data sets, such as the Uniform Crime Reports. For instance, whereas the Uniform Crime Reports contain information on all arrests and cleared offenses for the eight Index crimes, NIBRS consists of individual incident records for all eight index crimes and the 38 other offenses (Part II 
offenses) at the calendar date and hourly level (Rantala and Edwards 2001). Because of the detailed information about the incident, including the precise time and date of the incident, economists such as Dahl and Dellavegna (2009), Card and Dahl (2009), Jacob and Moretti (2003) and Lefgren, Jacobs and Moretti (2007) have used it for event studies. In our case, we exploit detailed information about the age of offenders and the crime's location - on school campuses or not - for our robustness checks.

Crimes follow a seasonal pattern. Figure 4 indicates a consistent pattern of gradual increases in both violent and non-violent crimes from winter to summer. Our method was developed to account for seasonality in both of our main variables of interest crime and games. Much of the seasonality in crimes is believed to be due to weather while seasonality in games is likely due to holiday gift giving (Lefgren, Jacobs and Moretti 2007). Failure to address this will likely lead to spurious correlations. As indicated above, we accommodate this in two ways. First, month dummy variables should capture much of the seasonality. Second, using Game Spot scores as IVs should isolate the variation in game sales due to game quality.

Our final sample includes 208 weekly observations on video games sales and crimes from early 2005 through 2008. However, eight observations are excluded from final regressions because of the use of lagged video game sales. Table 3 reports basic descriptive statistics for our sample.

\section{Results}

\section{A. Basic Results}

Our basic regression results are presented in Tables 4 and 5. Table 4 reports estimates of various specifications of the effect video games sales on all crimes from equation (1) above. Video games are separated between those that the ESRB rated as "intensely violent" 
and those that are not. Recall that the lesser rating of merely "violent" does not warrant an ESRB rating of "M." Control variables include month dummies to capture seasonality and a time trend to capture any secular trend. The columns from left to right add more lags of video games to the specification so as to measure possible inter-temporal effects of game purchase in one week affecting crime in subsequent weeks through continued play. Finally, each regression employs a 2SLS estimator with the same set of current and eight lags of Game Spot scores averaged over intensely violent games and over games that are not intensely violent. Since the specifications are over-identified, we test for possible endogeneity of the instrument set. As expected, in all cases, we fail to reject the exogeneity of Game Spot scores with respect to the level of crime.

The estimated effect of video games sales in any single week is small. Most individual coefficient estimates are negative but few are significantly different from zero. It appears that lags of up to five weeks of video game sales may be associated with current crime. It is not clear from this table whether violent games have a different effect from those that are not violent. For ease of comparison, we report the sum of the coefficients for various lags for both in the top panel of Table 6 to calculate the cumulative effect of a change in video games over time. Here it becomes clear that video games are estimated to have an overall negative effect on crime for specifications that include from one to five lags. That is, both violent and nonviolent games are associated with reductions in crimes. However, the effect is small. Since our specification is double log, these estimates can be interpreted as elasticities with values of up to -0.025 for non-violent games and -0.010 for violent games. These estimates suggest that, over all the mechanisms through which videogame play can affect crime, the net effect is to reduce crime.

\footnotetext{
${ }^{11}$ Unreported regressions comparing games that are either "intensely violent" or "violent" versus all other games generally yield much less precisely estimated parameters.
} 
These estimates may also allow us to make some inferences that distinguish between mechanisms. While both violent and non-violent games are hypothesized to have incapacitation effects, only violent games are hypothesized to alter behaviors. Indeed, the top panel of Table 6 indicates that the difference in effects between violent and non-violent games is for violent games to reduce crime by a smaller amount and that this difference is statistically significant for specifications that include between two and six lags. Moreover, it is not testable but it is likely that the incapacitation effect for violent games is even greater than for non-violent games. If so, the difference of these estimates may represent a downwardly biased estimate of a behavioral effect. This provides some support for the laboratory findings of a reinforcing behavioral effect that partially counterbalances the incapacitation effect.

Table 5 repeats these specifications for equation (2) where the dependent variable is now the log of fraction of crimes that are violent. By doing so, we attempt to control for any effect the video games might have on overall crime and concentrate on whether the composition of crime toward more violent crimes is affected by video game play. Again, we include various lags for the effects of video games and, again, more individual estimates are negative than positive but few are significantly different from zero. The bottom panel of Table 6 reports the aggregation of the lagged video game coefficients to calculate the cumulative effects. From this panel we usually find an overall negative effect of video games on the fraction of crimes that are violent, but that this effect is not statistically different from zero for specifications that include more than two lags and, for the others, is only marginally so. With that caveat, these estimates indicate that video game play is generally associated with reductions in the violent nature of the crimes committed.

The test for a difference in the effects for violent and non-violent games may be more informative. There are no known previously hypothesized mechanisms through which non- 
violent games would affect the violent composition of crimes. We can speculate that nonviolent games "teach good behavior" but this has not been proposed before. Whatever the mechanism, this suggests that the appropriate test for violent video games affecting violent behavior is the difference in these effects by game type. In this case, the marginal effect violent video games is to increase the violent nature of crimes, but this difference in effects is only marginally significant in the second column and the estimated difference is small with an implicit elasticity of 0.02 . That is, if intensely violent game sales doubled, then apart from any incapacitation effect or any "teaching good behavior" effect, this would lead to an increase in violent crimes of up to $2 \%$.

\section{B. Age of Offender Results}

A potential robustness check is to examine the effects of video games on criminal offenders by age of offender. While the age profile of video game players is increasing, video games are still primarily played by children, teens and younger adults. For most offenses, the NIBRS data records information on the age of the offenders for an incident. We separately examine the effects of video game sales on those aged 15-30, the prime video game playing population, versus those $35-50$, a population for which video game play is not as popular. If our basic results were spurious and did not reflect any direct link between video game play and criminal acts, we would have no reason to expect a differential spurious effect by age group. In contrast, under our hypotheses, we would expect larger effects for the younger group.

Table 7 reports cumulative estimates from estimating equation (1) for both these younger and older groups. The specifications are otherwise identical to those reported in Table 4. However, rather than report the individual estimates as in Tables 4 and 5, we report the estimated sums over all lags as in Table 6. As before, specifications with lags from between two and five achieve some level of statistical significance for both the young and the 
old. The estimated effects of both violent and non-violent video games are both negative, as before. And, as before, violent video games decrease crime by less than do non-violent video games. That is, there are few, if any, qualitative differences across the two groups.

Table 8 reports cumulative estimates from estimating equation (2), where the dependent variable is the logarithm of the fraction of crimes that are violent, for both these younger and older groups. The specifications are otherwise identical to those reported in Table 5 and again we report the estimated sum of effects over all lags as in Table 6. Now, there are noticeable differences across the two groups. None of the estimates for the older group approach traditional levels of statistical significance. In contrast, the estimates for the younger group are generally larger (in absolute value) than those in the lower panel of Table 6 and more often reach statistical significance. In addition, the differences in estimates between violent and nonviolent games are larger and are more often statistically significant. We again find that, for the younger group, non-violent games, as well as violent games, reduce the fraction of crimes that are violent. As before we are unsure what the mechanism is that would lead non-violent games to reduce violent crimes, but we hypothesize that, in addition to this mechanism, violent games also could increase gamers violent behaviors as indicated by the laboratory experiments. In these specifications, this is measured by the difference between the coefficients in the two rows which is measured to be as large as 0.07 . Thus, this is evidence that the behavioral effect of violent video games on violent behavior is found only within the population that plays video games more intensively.

\section{On Campus Results}

Another potential robustness check is to distinguish between crimes committed at schools and colleges and those committed elsewhere. Schools and colleges tend to aggregate people who are of video game playing age. The NIBRS data record the location of each incident as a categorical variable where one possible choice out of eleven is "school or college 
campus." One advantage of this variable over the age of offender variable is that it is recorded for all incidents while the age of offender can be missing if no one witnessed the incident in progress. One disadvantage is that crimes committed at schools and colleges need not be committed by a member of the younger video game playing demographic, though most are. Perhaps a bigger problem is that many of the younger video game playing population commit crimes away from schools. Finally, since such a small number of crimes are committed on campus, we may lose statistical power for that sub-sample while the off-campus sub-sample will be quite similar to the overall sample.

Table 9 reports cumulative estimates from estimating equation (1) for both crimes committed on campuses and those committed off-campus. The specifications are otherwise identical to those reported in Table 4 but we report the estimated cumulative effect over all lags as in Table 6. As before, specifications with lags from between two and five achieve some level of statistical significance for both the young and the old. The pattern of estimated effects for both violent and non-violent video games is similar to before except that they are much larger for on-campus crimes than off-campus. In the lower panel, the estimates are qualitatively similar to the base results in Table 6. However, the upper panel estimates are about five times larger. Other than the difference in magnitudes, the pattern of effects oncampus is unchanged. There is still a negative effect for non-violent video games in columns 2-5 that we interpret as an incapacitation effect. The estimated effect for violent video games is statistically significantly smaller (in absolute value) and we interpret the difference as a possible estimate of a behavioral effect of violent video games on crime.

Table 10 reports cumulative estimates from estimating equation (2), where the dependent variable is the logarithm of the fraction of crimes that are violent, for both crimes on and off campus. The specifications are otherwise identical to those reported in Table 2 and again we report the estimated sum of effects over all lags as in Table 6. In this case, few 
effects are estimated to be significantly different from zero. In contrast to before, non-violent games may increase the violent composition of crimes on campus, holding all crimes constant but only in column 1 . As expected, the off-campus results are more similar our basic results reported in the bottom panel of Table 6 .

\section{Conclusion}

Regulation of the video game industry is usually predicated on the notion that the industry has large and negative social costs through games' effect on aggression. Many researchers have argued that these games may also have caused extreme violence, such as school shootings, because laboratory evidence has found an abundance of evidence linking gameplay to aggression. Yet few studies before this one had examined the impact of these games on crime, with the exception of Ward (2011) and Dahl and Dellavegna (2009). Consistent with these studies, we find that the social costs of violent video games may be considerably lower, or even non-existent, once one incorporates the time use effect into analysis.

These analyses are suggestive of the hypothesis that violent video games, like all video games, paradoxically may reduce violence while increasing the aggressiveness of individuals by simply shifting these individuals out of alternative activities where crime is more likely to occur. Insofar as our findings suggest that the operating mechanism by which violent gameplay causes crime to fall is the gameplay itself, and not the violence, then regulations should be carefully designed so as to avoid inadvertently reducing the time intensity, or the appeal, of video games.

Our findings also suggest unique challenges to game regulations. Because GAM proposes that the individual playing violent video games is developing, accidentally, a biased 
hermeneutic towards people wherein they believe they are in danger, then the decrease in violent outcomes that we observe in our study - the incapacitation effect from time use - may be masking the long-run harm to society if these violent behaviors are developing within gamers. This suggests that regulation aimed at reducing violent imagery and content in games could in the long-run reduce the aggression capital stock among gamers, but potentially also cause crime to increase in the short-run if the marginal player is being drawn out of violent activities. This may be too costly a tradeoff, and may not pass any cost-benefit test. But another possibility is that individuals who play games could be regularly taught to recognize these errors in their framing of situations, which theoretically would reduce the aggressive capital and thus reduce any negative outcome that is determined by the amount of aggression the person has built up, without losing the short-run gains from crime reduction. 


\section{References}

Anderson, Craig A. (2004). "An update on the effects of playing violent video games," Journal of Adolescence 27, 113-122.

Anderson, Craig A, Douglas A. Gentile, Katherine E. Buckley. (2007) Violent video game effects on children and adolescents: theory, research and public policy. Oxford University Press, 1st edition.

Anderson, C. A. and B. J. Bushman. 2002. "Human aggression.” Annual Review of Psychology, 53:27-51.

Angrist, J. D. (2006). "Instrumental variables methods in experimental criminological research: what, why and how.” Journal of Experimental Criminology 2: 23-44.

Becker, Gary S. (1965). “A theory of the allocation of time.” Economic Journal 75 (299), pp. 493-517.

Becker, Gary and Kevin M. Murphy (1988). "A theory of rational addiction." The Journal of Political Economy 96: p. 675-700.

Berk, R (2005). "Randomized experiments as the bronze standard." Journal of Experimental Criminology. 1:417-433.

B. J. Bushman and C. A. Anderson (2002). "Violent video games and hostile expectations: a test of the general aggression model." Personality and Social Psychology Bulletin 28 (12): 1679-1686.

D. T. Campbell and J. C. Stanley (1963). Experimental and quasi-experimental designs for research. Chicago: Rand McNally.

Card, David and Gordon B. Dahl (2011). "Family violence and football: the effect of unexpected emotional cues on violent behaviour." Quarterly Journal of Economics (forthcoming).

Comstock, Anthony and J. M. Buckley (1883) Traps for the young. Republished in 1967 by Beknap Press, First Edition edition.

Dahl, Gordon and Stefano DellaVigna (2009). "Does movie violence increase violent crime?" Quarterly Journal of Economics, 124(2) 637-675.

Deaton, A. (2010). "Instruments, randomization, and learning about development." Journal of Economic Literature 48: 424-455.

Ferguson, C. J. and J. Kilburn (2008). "The public health risks of media violence: a metaanalytic review." The Journal of Pediatrics 154(4): 759-763.

Fisher, R. A. (1935). The design of experiments. Oliver and Boyd, Edinburgh.

Gould, E. D., B. A. Weinberg and D. B. Mustard (2002). "Crime rates and local labor market opportunities in the united states: 1979-1997." The Review of Economics and Statistics 84(1): 45-61

Hadju David (2009), The ten-cent plague: the great comic-book scare and how it changed america. New York: Farrar, Strauss and Giroux. 
Harrison, G. W. and J. A. List (2004). "Field experiments.” Journal of Economic Literature 42(4): 1013-1059.

Heckman, J. and S. Urzua (2010) "Comparing IV with structural models: what simple IV can and cannot identify." Journal of Econometrics 156 (1): 27-37.

Imbens, G. W. (2010). Better LATE Than Nothing: Some Comments on Deaton (2009) and Heckman and Urzua (2009). Journal of Economic Literature 48(2): 399-423.

Hilger, James, Greg Rafert and Sofia Villas-Boas (2010). "Expert opinion and the demand for experience goods: an experimental approach in the retail wine market." Review of Economics \& Statistics, forthcoming.

Jacob, B. A., and E. Moretti (2003). "Are idle hands the devil's workshop? incapacitation, concentration, and juvenile crime." The American Economic Review 93 (5): 15601577 .

Jacob, B. A., L. Lefgren and E Moretti (2007). "The dynamics of criminal behavior: evidence from weather shocks.” Journal of Human Resources 42 (3): 489-527.

Kutner, Lawrence and Cheryl Olson (2008). Grand theft childhood: the surprising truth about violent video games and what parents can do. Simon \& Schuster.

Rantala, Ramona R and Thomas J. Edwards (2000). "Effects of NIBRS on crime statistics". NCJ Publication 178890. US Department of Justice.

Raphael, S. and R. Winter-Ebmer (2001). "Identifying the effect of unemployment on crime." Journal of Law and Economics 44: 259-283.

Reinstein, D. and C. Snyder (2005). "The influence of expert reviews on consumer demand for experience goods: A case study of movie critics." Journal of Industrial Economics 53(1): 27-51.

Rosenbaum, P. R. (2002) Observational studies. New York: Springer.

Rosenbaum, P. R. (2002). "Covariance adjustment in randomized experiments and observational studies." Statistical Science 17(3): 286-304.

Stinebrickner, Ralph Todd R. Stinebrickner (2008). "The causal effect of studying on academic performance." The B.E. Journal of Economic Analysis \& Policy: Frontiers 8(1) Article 14.

Ward, Michael R. (2010). "Video games and adolescent fighting." Journal of Law and Economics, 53(3) 611-628.

Ward, Michael R. (2011). "Video games and crime." Contemporary Economic Policy. 29(2) 261-273.

Zhu, Feng and Xiaoquan (Michael) Zhang (2010). "Impact of online consumer reviews on sales: the moderating role of product and consumer characteristics." Journal of Marketing, Vol. 74 (March 2010), 133-148. 
Figure 1

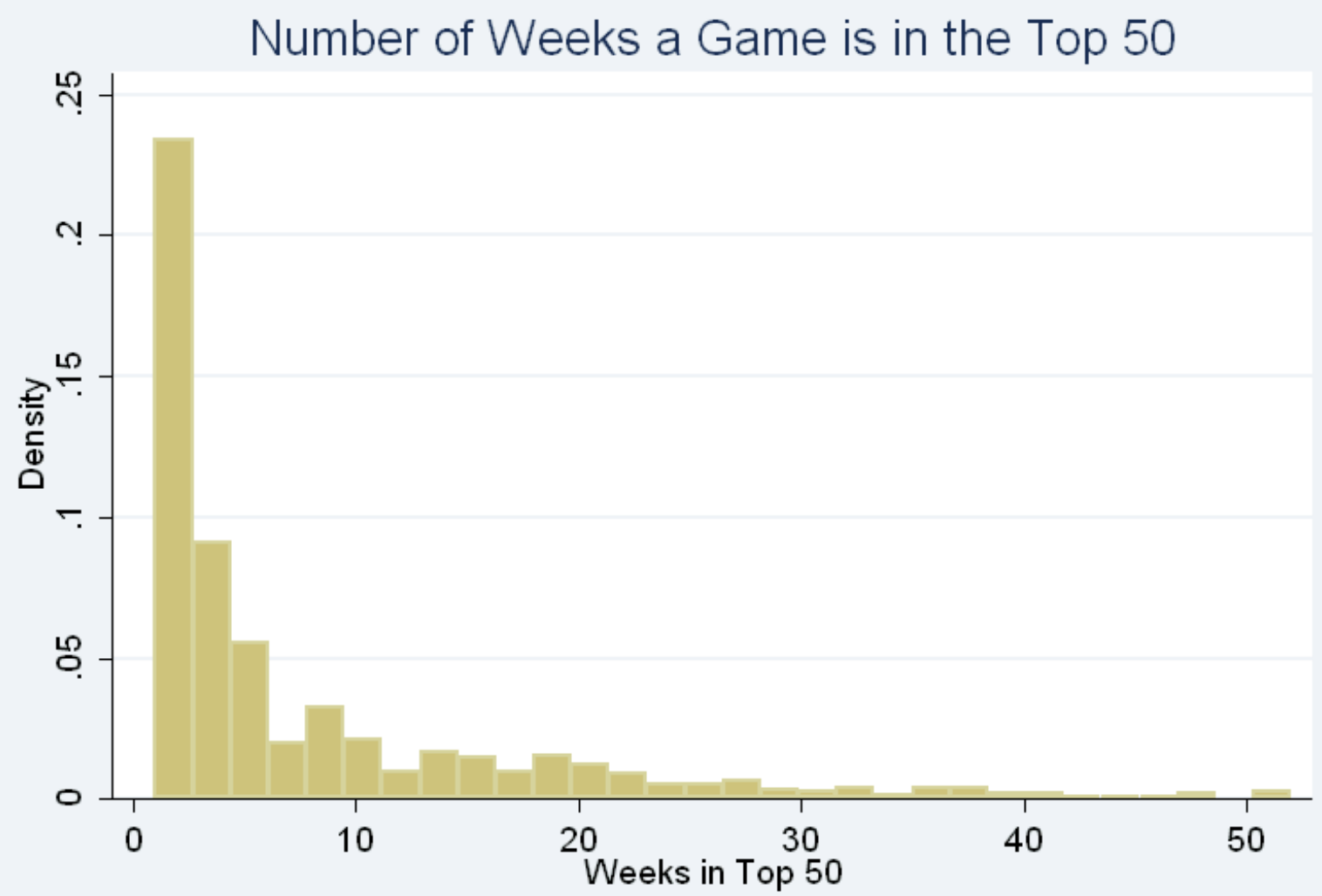

Excludes $2.5 \%$ of games that were ranked in the top 50 for more than a year 
Figure 2

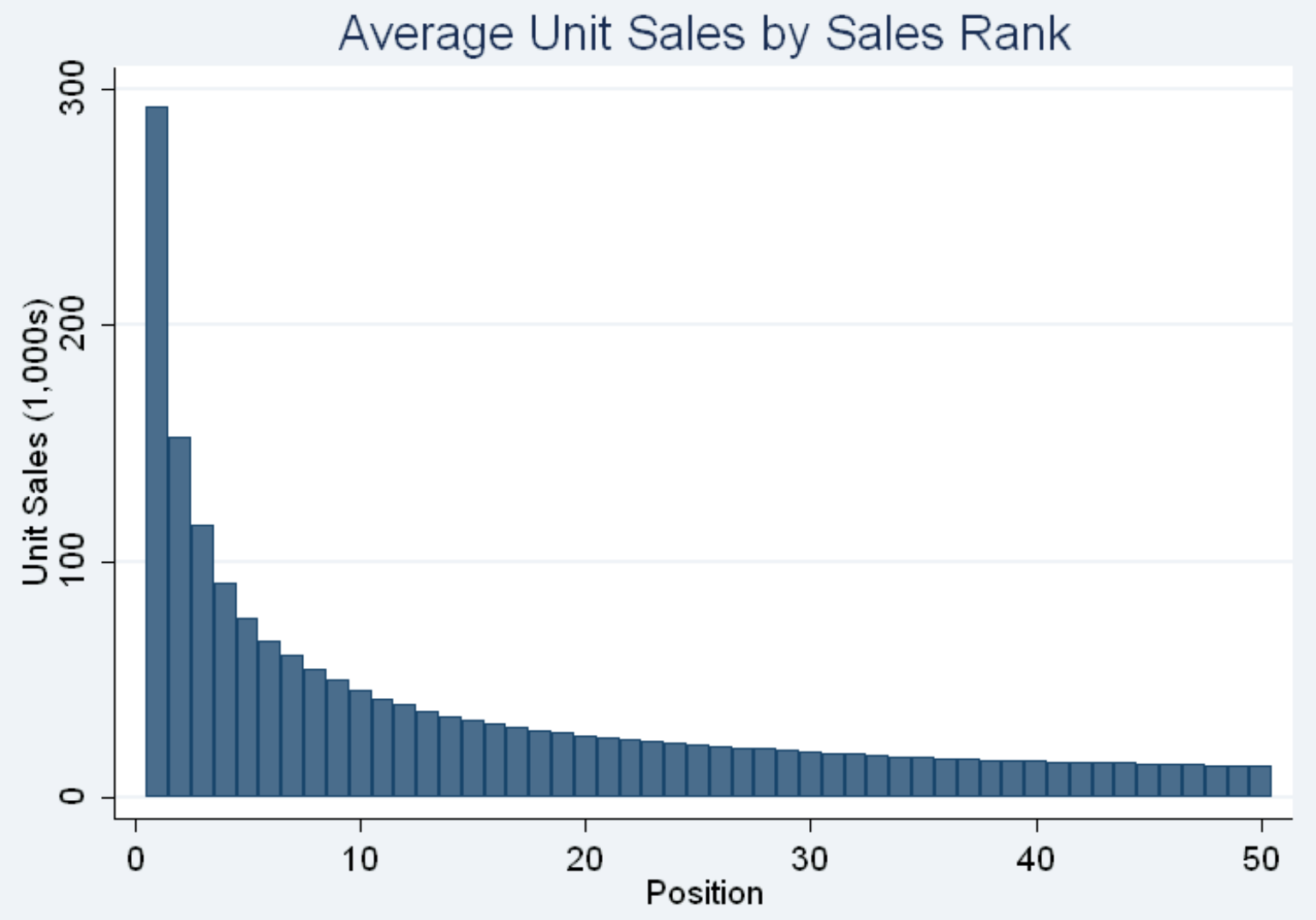


Figure 3

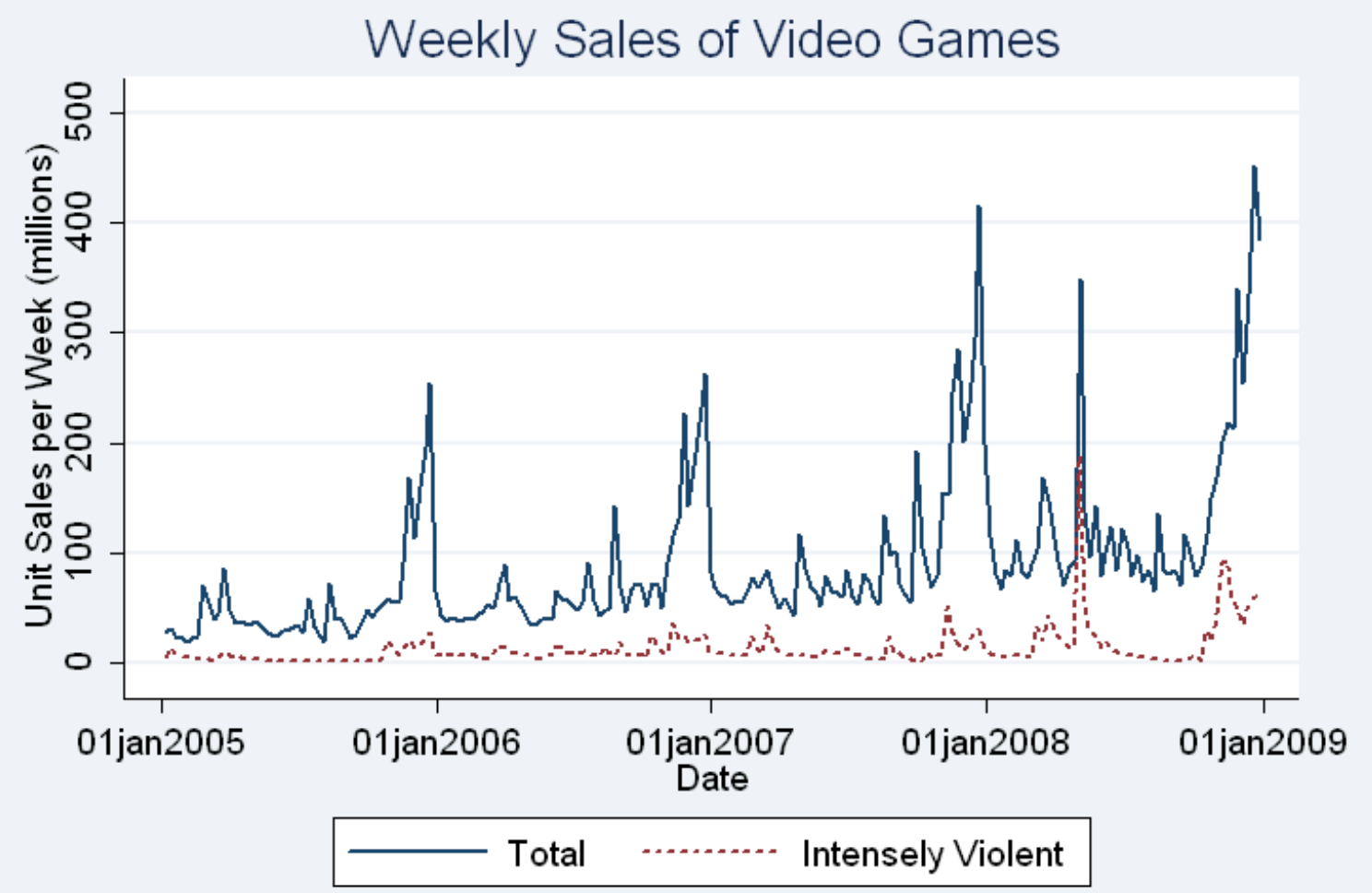


Figure 4

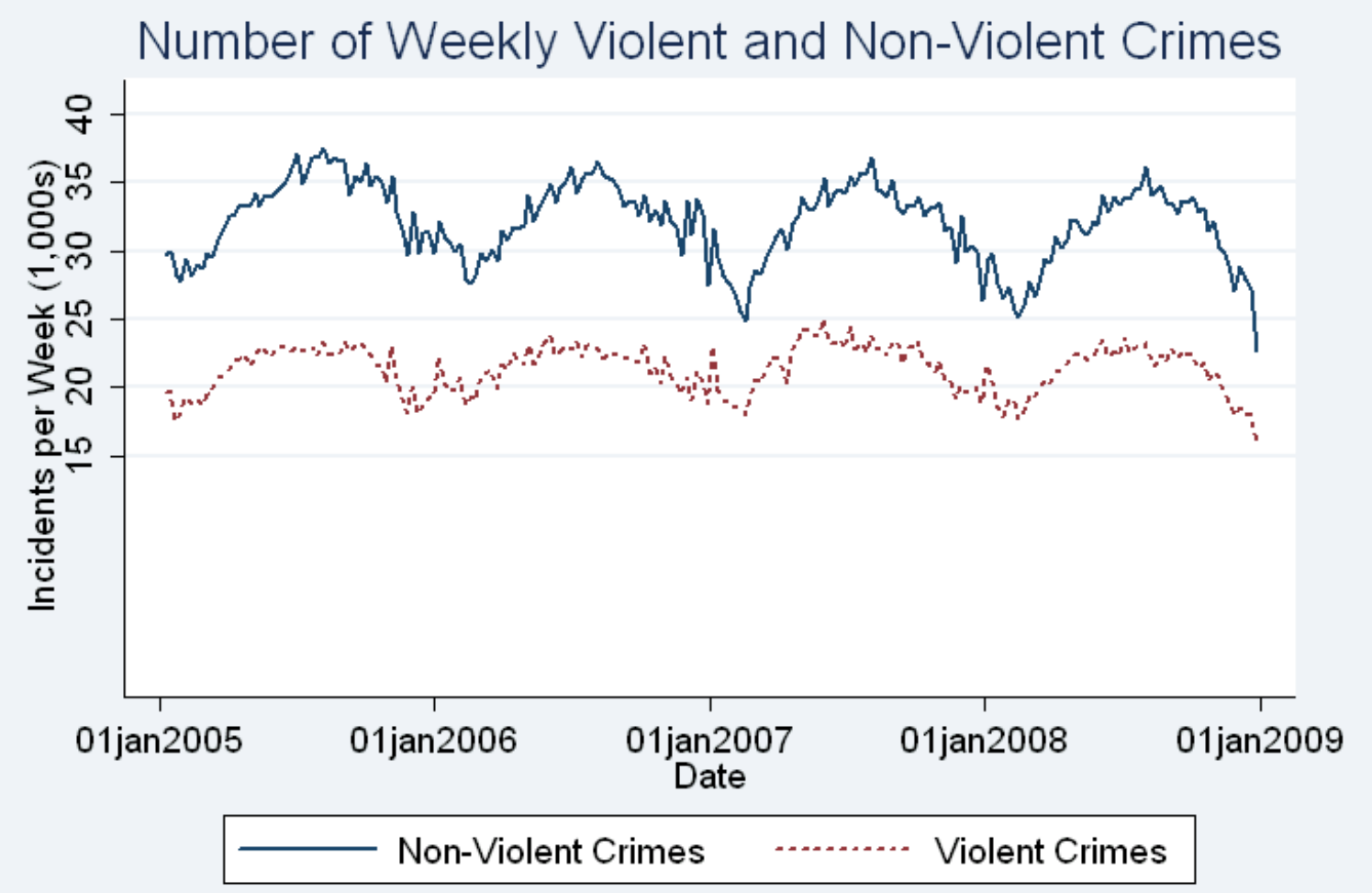




\section{Table 1}

Unit Sales of Video Games (millions) from VGChartz and ESA

\begin{tabular}{rrrr}
\hline Year & VGChartz & ESA & Pct \\
\hline 2005 & 56.7 & 240.7 & $23.6 \%$ \\
2006 & 76.2 & 267.8 & $28.5 \%$ \\
2007 & 107.0 & 298.2 & $35.9 \%$ \\
2008 & 141.3 & 273.5 & $51.7 \%$ \\
\hline
\end{tabular}

VGChartz from authors' calculations and ESA from

http://www.theesa.com/facts/pdfs/VideoGames21stCentury_2010.pdf. 
Table 2

The Effect of Game Quality (Game Spot Score) on Log Sales

\begin{tabular}{|c|c|c|c|}
\hline & $\begin{array}{c}\text { All } \\
\text { Games }\end{array}$ & $\begin{array}{c}\text { Intensely Violent } \\
\text { Games }\end{array}$ & $\begin{array}{c}\text { Not Intensely Violent } \\
\text { Games }\end{array}$ \\
\hline GameSpot & $0.0803^{* *}$ & $0.1221 * *$ & $0.0769 * *$ \\
\hline Score & $(0.0060)$ & $(0.0181)$ & $(0.0065)$ \\
\hline Week of & $-0.0039 * *$ & $-0.0081 * *$ & $-0.0036 * *$ \\
\hline Release & $(0.0002)$ & $(0.0008)$ & $(0.0003)$ \\
\hline \multirow[t]{2}{*}{ Trend } & $0.0058 * *$ & $0.0040 * *$ & $0.0060 * *$ \\
\hline & $(0.0001)$ & $(0.0003)$ & $(0.0001)$ \\
\hline \multirow[t]{2}{*}{ February } & $-0.0902 *$ & $-0.2169^{*}$ & $-0.0663+$ \\
\hline & $(0.0361)$ & $(0.1020)$ & $(0.0385)$ \\
\hline \multirow[t]{2}{*}{ March } & -0.0212 & -0.0576 & -0.0081 \\
\hline & $(0.0348)$ & $(0.0967)$ & $(0.0371)$ \\
\hline \multirow[t]{2}{*}{ April } & $-0.1770 * *$ & $-0.3466 * *$ & $-0.1361 * *$ \\
\hline & $(0.0344)$ & $(0.0945)$ & $(0.0369)$ \\
\hline \multirow[t]{2}{*}{ May } & $-0.2838 * *$ & $-0.4069 * *$ & $-0.2485 * *$ \\
\hline & $(0.0355)$ & $(0.1004)$ & $(0.0378)$ \\
\hline \multirow[t]{2}{*}{ June } & $-0.1663^{* *}$ & $-0.3593 * *$ & $-0.1217 * *$ \\
\hline & $(0.0363)$ & $(0.1036)$ & $(0.0386)$ \\
\hline \multirow[t]{2}{*}{ July } & $-0.2251 * *$ & $-0.5266 * *$ & $-0.1732 * *$ \\
\hline & $(0.0358)$ & $(0.1059)$ & $(0.0378)$ \\
\hline \multirow[t]{2}{*}{ August } & $-0.3607 * *$ & $-0.6881 * *$ & $-0.3126 * *$ \\
\hline & $(0.0364)$ & $(0.1151)$ & $(0.0381)$ \\
\hline \multirow[t]{2}{*}{ September } & $-0.2700 * *$ & $-0.4117 * *$ & $-0.2422 * *$ \\
\hline & $(0.0358)$ & $(0.1200)$ & $(0.0374)$ \\
\hline \multirow[t]{2}{*}{ October } & $-0.1326^{* *}$ & 0.0065 & $-0.1333 * *$ \\
\hline & $(0.0365)$ & $(0.1159)$ & $(0.0383)$ \\
\hline \multirow[t]{2}{*}{ November } & $0.6122 * *$ & $0.6812 * *$ & $0.6051 * *$ \\
\hline & $(0.0361)$ & $(0.1052)$ & $(0.0382)$ \\
\hline \multirow[t]{2}{*}{ December } & $1.2038^{* *}$ & $1.1363 * *$ & $1.2153 * *$ \\
\hline & $(0.0349)$ & $(0.1073)$ & $(0.0367)$ \\
\hline \multirow[t]{2}{*}{ Constant } & $-4.8503^{* *}$ & -0.5994 & $-5.3472 * *$ \\
\hline & $(0.2957)$ & $(0.8309)$ & $(0.3189)$ \\
\hline Observations & 10,648 & 1,345 & 9,303 \\
\hline R-squared & 0.38 & 0.40 & 0.38 \\
\hline $\begin{array}{l}\text { Standard error } \\
+ \text { significant a }\end{array}$ & $\begin{array}{l}\text { rentheses } \\
* \text { significa }\end{array}$ & $\%$;** significant & \\
\hline
\end{tabular}


Table 3

Summary Statistics

\begin{tabular}{lrc}
\hline Variable & \multicolumn{1}{c}{ Mean } & Std. Dev. \\
\hline Ln All Video Game Sales & 0.407 & 0.632 \\
Ln Intensely Violent Video Game Sales & -1.900 & 1.037 \\
Ln Not Intensely Violent Video Game Sales & 0.781 & 0.340 \\
Average GameSpot Score & 7.634 & 0.435 \\
Average Intensely Violent GameSpot Score & 8.546 & 0.646 \\
Average Not Intensely Violent GameSpot Score & 7.506 & 0.468 \\
Ln All Crimes & 10.889 & 0.085 \\
Ln Violent Share of All Crimes & 3.689 & 0.028 \\
Ln All Crimes on Campuses & 7.463 & 0.421 \\
Ln Violent Share of All Crimes on Campuses & 3.796 & 0.107 \\
Ln All Crimes Not on Campuses & 10.852 & 0.091 \\
Ln Violent Share of All Crimes Not on Campuses & 3.683 & 0.028 \\
Ln All Crimes Offender Aged 15-30 & 9.854 & 0.068 \\
Ln Violent Share of All Crimes Offender 15-30 & 4.117 & 0.024 \\
Ln All Crimes Offender Aged 35-50 & 9.040 & 0.082 \\
Ln Violent Share of All Crimes Offender 35-50 & 4.172 & 0.022 \\
\hline Descriptive statistics of the 200 observations used in later tables. & \\
\hline
\end{tabular}


Table 4

The Effects of Video Game Sales on the Log of both Violent and Non-Violent Crime

\begin{tabular}{|c|c|c|c|c|c|c|c|}
\hline & $(1)$ & $(2)$ & (3) & $(4)$ & $(5)$ & $(6)$ & $(7)$ \\
\hline Ln Video Game Sales & -0.028 & 0.029 & 0.030 & 0.041 & 0.042 & 0.032 & 0.044 \\
\hline Not Intensely Violent & $(0.60)$ & $(0.50)$ & $(0.44)$ & $(0.54)$ & $(0.52)$ & $(0.40)$ & $(0.55)$ \\
\hline Ln VG Sales Not & & $-0.130+$ & -0.110 & -0.090 & -0.089 & -0.099 & -0.088 \\
\hline Intensely Violent lag 1 & & $(1.92)$ & $(1.35)$ & $(1.03)$ & $(1.03)$ & $(1.15)$ & $(1.02)$ \\
\hline Ln VG Sales Not & & & $-0.131+$ & -0.098 & -0.095 & -0.044 & -0.040 \\
\hline Intensely Violent lag 2 & & & $(1.71)$ & $(1.16)$ & $(1.13)$ & $(0.50)$ & $(0.46)$ \\
\hline Ln VG Sales Not & & & & -0.068 & -0.067 & -0.064 & -0.075 \\
\hline Intensely Violent lag 3 & & & & $(0.91)$ & $(0.88)$ & $(0.86)$ & $(0.90)$ \\
\hline Ln VG Sales Not & & & & & 0.010 & 0.042 & 0.029 \\
\hline Intensely Violent lag 4 & & & & & $(0.12)$ & $(0.53)$ & $(0.35)$ \\
\hline Ln VG Sales Not & & & & & & $-0.125+$ & $-0.126+$ \\
\hline Intensely Violent lag 5 & & & & & & $(1.73)$ & $(1.72)$ \\
\hline Ln VG Sales Not & & & & & & & 0.026 \\
\hline Intensely Violent lag 6 & & & & & & & $(0.30)$ \\
\hline Ln Intensely Violent & -0.009 & 0.014 & 0.019 & 0.030 & 0.031 & 0.023 & 0.026 \\
\hline Video Game Sales & $(0.44)$ & $(0.56)$ & $(0.64)$ & $(0.94)$ & $(0.94)$ & $(0.71)$ & $(0.81)$ \\
\hline Ln Intensely Violent & & $-0.055+$ & -0.043 & -0.029 & -0.029 & -0.034 & -0.027 \\
\hline VG Sales lag 1 & & $(1.77)$ & $(1.11)$ & $(0.70)$ & $(0.69)$ & $(0.83)$ & $(0.65)$ \\
\hline Ln Intensely Violent & & & $-0.063+$ & -0.044 & -0.042 & -0.021 & -0.017 \\
\hline VG Sales lag 2 & & & $(1.72)$ & $(1.06)$ & $(1.02)$ & $(0.49)$ & $(0.39)$ \\
\hline Ln Intensely Violent & & & & -0.048 & -0.047 & -0.047 & -0.051 \\
\hline VG Sales lag 3 & & & & $(1.41)$ & $(1.27)$ & $(1.29)$ & $(1.22)$ \\
\hline Ln Intensely Violent & & & & & 0.001 & 0.011 & 0.006 \\
\hline VG Sales lag 4 & & & & & $(0.04)$ & $(0.29)$ & $(0.15)$ \\
\hline Ln Intensely Violent & & & & & & -0.036 & -0.032 \\
\hline VG Sales lag 5 & & & & & & $(1.10)$ & $(0.91)$ \\
\hline Ln Intensely Violent & & & & & & & -0.000 \\
\hline VG Sales lag 6 & & & & & & & $(0.01)$ \\
\hline \multicolumn{8}{|c|}{$\begin{array}{l}\text { Sample includes } 200 \text { weekly observations from 2004-2008. Month dummy variables and a time trend were also } \\
\text { included but are not reported. Average GameSpot scores for intensely violent and not for the current period and eight } \\
\text { lags are used as IVs. The Sargon statistic for over-identification always fails to reject the exogeneity of the instrument } \\
\text { set. Absolute value of z-statistics in parentheses. + significant at } 10 \% ; * \text { significant at } 5 \% \text {; ** significant at } 1 \% \text {. }\end{array}$} \\
\hline
\end{tabular}


Table 5

The Effects of Video Game Sales on the Log of the Fraction of Crime that is Violent

\begin{tabular}{|c|c|c|c|c|c|c|c|}
\hline & $(1)$ & $(2)$ & (3) & (4) & $(5)$ & $(6)$ & $(7)$ \\
\hline $\begin{array}{l}\text { Ln Video Game Sales } \\
\text { Not Intensely Violent }\end{array}$ & $\begin{array}{c}-0.033+ \\
(1.72)\end{array}$ & $\begin{array}{l}-0.024 \\
(1.05)\end{array}$ & $\begin{array}{l}-0.020 \\
(0.78)\end{array}$ & $\begin{array}{l}-0.043 \\
(1.51)\end{array}$ & $\begin{array}{l}-0.041 \\
(1.39)\end{array}$ & $\begin{array}{l}-0.047 \\
(1.48)\end{array}$ & $\begin{array}{l}-0.050 \\
(1.55)\end{array}$ \\
\hline $\begin{array}{l}\text { Ln VG Sales Not } \\
\text { Intensely Violent lag } 1\end{array}$ & & $\begin{array}{l}-0.021 \\
(0.77)\end{array}$ & $\begin{array}{l}-0.023 \\
(0.79)\end{array}$ & $\begin{array}{l}-0.014 \\
(0.43)\end{array}$ & $\begin{array}{l}-0.013 \\
(0.40)\end{array}$ & $\begin{array}{l}-0.013 \\
(0.37)\end{array}$ & $\begin{array}{l}-0.017 \\
(0.50)\end{array}$ \\
\hline $\begin{array}{l}\text { Ln VG Sales Not } \\
\text { Intensely Violent lag } 2\end{array}$ & & & $\begin{array}{l}-0.015 \\
(0.53)\end{array}$ & $\begin{array}{l}-0.038 \\
(1.21)\end{array}$ & $\begin{array}{l}-0.036 \\
(1.15)\end{array}$ & $\begin{array}{l}-0.053 \\
(1.52)\end{array}$ & $\begin{array}{l}-0.051 \\
(1.41)\end{array}$ \\
\hline $\begin{array}{l}\text { Ln VG Sales Not } \\
\text { Intensely Violent lag } 3\end{array}$ & & & & $\begin{array}{l}0.065^{*} \\
(2.34)\end{array}$ & $\begin{array}{l}0.067 * \\
(2.36)\end{array}$ & $\begin{array}{l}0.070 * \\
(2.33)\end{array}$ & $\begin{array}{c}0.064+ \\
(1.87)\end{array}$ \\
\hline $\begin{array}{l}\text { Ln VG Sales Not } \\
\text { Intensely Violent lag } 4\end{array}$ & & & & & $\begin{array}{l}0.001 \\
(0.04)\end{array}$ & $\begin{array}{l}-0.010 \\
(0.31)\end{array}$ & $\begin{array}{l}0.000 \\
(0.00)\end{array}$ \\
\hline $\begin{array}{l}\text { Ln VG Sales Not } \\
\text { Intensely Violent lag } 5\end{array}$ & & & & & & $\begin{array}{c}0.052+ \\
(1.79)\end{array}$ & $\begin{array}{l}0.048 \\
(1.59)\end{array}$ \\
\hline $\begin{array}{l}\text { Ln VG Sales Not } \\
\text { Intensely Violent lag } 6\end{array}$ & & & & & & & $\begin{array}{l}0.014 \\
(0.40)\end{array}$ \\
\hline $\begin{array}{l}\text { Ln Intensely Violent } \\
\text { Video Game Sales }\end{array}$ & $\begin{array}{c}-0.015+ \\
(1.88)\end{array}$ & $\begin{array}{l}-0.015 \\
(1.45)\end{array}$ & $\begin{array}{l}-0.015 \\
(1.38)\end{array}$ & $\begin{array}{c}-0.022+ \\
(1.84)\end{array}$ & $\begin{array}{c}-0.021+ \\
(1.70)\end{array}$ & $\begin{array}{c}-0.023+ \\
(1.72)\end{array}$ & $\begin{array}{c}-0.023+ \\
(1.71)\end{array}$ \\
\hline $\begin{array}{l}\text { Ln Intensely Violent } \\
\text { VG Sales lag } 1\end{array}$ & & $\begin{array}{l}-0.004 \\
(0.36)\end{array}$ & $\begin{array}{l}-0.006 \\
(0.43)\end{array}$ & $\begin{array}{l}-0.000 \\
(0.01)\end{array}$ & $\begin{array}{l}0.000 \\
(0.01)\end{array}$ & $\begin{array}{l}-0.001 \\
(0.07)\end{array}$ & $\begin{array}{l}-0.004 \\
(0.24)\end{array}$ \\
\hline $\begin{array}{l}\text { Ln Intensely Violent } \\
\text { VG Sales lag } 2\end{array}$ & & & $\begin{array}{l}-0.003 \\
(0.26)\end{array}$ & $\begin{array}{l}-0.017 \\
(1.13)\end{array}$ & $\begin{array}{l}-0.016 \\
(1.06)\end{array}$ & $\begin{array}{l}-0.023 \\
(1.36)\end{array}$ & $\begin{array}{l}-0.023 \\
(1.30)\end{array}$ \\
\hline $\begin{array}{l}\text { Ln Intensely Violent } \\
\text { VG Sales lag } 3\end{array}$ & & & & $\begin{array}{l}0.026^{*} \\
(2.03)\end{array}$ & $\begin{array}{l}0.028 * \\
(2.01)\end{array}$ & $\begin{array}{c}0.029 * \\
(1.99)\end{array}$ & $\begin{array}{l}0.025 \\
(1.47)\end{array}$ \\
\hline $\begin{array}{l}\text { Ln Intensely Violent } \\
\text { VG Sales lag } 4\end{array}$ & & & & & $\begin{array}{l}-0.002 \\
(0.14)\end{array}$ & $\begin{array}{l}-0.010 \\
(0.69)\end{array}$ & $\begin{array}{l}-0.006 \\
(0.35)\end{array}$ \\
\hline $\begin{array}{l}\text { Ln Intensely Violent } \\
\text { VG Sales lag } 5\end{array}$ & & & & & & $\begin{array}{c}0.025+ \\
(1.93)\end{array}$ & $\begin{array}{l}0.021 \\
(1.44)\end{array}$ \\
\hline $\begin{array}{l}\text { Ln Intensely Violent } \\
\text { VG Sales lag } 6\end{array}$ & & & & & & & $\begin{array}{l}0.011 \\
(0.63) \\
\end{array}$ \\
\hline $\begin{array}{l}\text { Sample includes } 200 \text { weekl } \\
\text { included but are not reporte } \\
\text { The Sargon statistic for ove } \\
\text { value of } z \text {-statistics in paren }\end{array}$ & $\begin{array}{l}\text { ntificatio } \\
\text { s. + sign }\end{array}$ & peve & reject $t$ & xogeneit & $\begin{array}{l}\text { the inst } \\
\text { gnifican }\end{array}$ & $1 \%$. & $\begin{array}{l}\text { also } \\
\text { ed as IVs. } \\
\text { lute }\end{array}$ \\
\hline
\end{tabular}


Table 6

The Cumulative Effect of Video Games on Crimes

Aggregate Effect on all Crimes (from Table 1)

\begin{tabular}{lccccccc} 
& \multicolumn{7}{c}{ Number of Lags Included } \\
& 0 & 1 & 2 & 3 & 4 & 5 & 6 \\
\hline Not Intensely & -0.028 & -0.101 & $-0.210^{*}$ & $-0.214^{*}$ & -0.200 & $-0.256^{*}$ & -0.229 \\
Violent Coefs. & $(0.046)$ & $(0.062)$ & $(0.096)$ & $(0.105)$ & $(0.122)$ & $(0.124)$ & $(0.140)$ \\
Intensely & -0.009 & -0.041 & $-0.087^{*}$ & $-0.092^{*}$ & $-0.086+$ & $-0.104^{*}$ & -0.095 \\
Violent Coefs. & $(0.020)$ & $(0.027)$ & $(0.040)$ & $(0.044)$ & $(0.049)$ & $(0.050)$ & $(0.056)$ \\
\hline $\begin{array}{l}\text { Chi-Sq test of } \\
\text { difference }\end{array}$ & 0.44 & 2.67 & $4.69^{*}$ & $3.76+$ & 2.33 & $4.07 *$ & 2.46 \\
\hline
\end{tabular}

Aggregate Effect on all Fraction of Crimes that are Violent (from Table 2)

Violent/

Number of Lags Included

\begin{tabular}{lccccccc} 
All Crimes & 0 & 1 & 2 & 3 & 4 & 5 & 6 \\
\hline Not Intensely & $-0.033+$ & $-0.045+$ & $-0.058+$ & -0.030 & -0.022 & -0.001 & 0.007 \\
Violent Games & $(0.019)$ & $(0.025)$ & $(0.035)$ & $(0.039)$ & $(0.045)$ & $(0.050)$ & $(0.057)$ \\
Intensely & $-0.015+$ & $-0.019+$ & $-0.024+$ & -0.014 & -0.011 & 0.002 & 0.001 \\
Violent Games & $(0.008)$ & $(0.011)$ & $(0.015)$ & $(0.016)$ & $(0.018)$ & $(0.020)$ & $(0.022)$ \\
\hline $\begin{array}{l}\text { Chi-Sq test of } \\
\text { difference }\end{array}$ & 2.22 & $2.95+$ & 2.60 & 0.48 & 0.17 & 0.00 & 0.03
\end{tabular}

For both the top and bottom panels, each column represents results from a separate instrumental variables regression. Each row reports the sum of coefficients for a variable for different possible lag lengths. Not reported are coefficients of month dummies and a time trend. Absolute value of $\mathrm{z}$-statistics in parentheses. + significant at $10 \% ; *$ significant at $5 \%$; * significant at $1 \%$ 
Table 7

The Effect of Video Games on both Violent and Non-Violent Crimes

By Offenders Aged 15-30 versus Offenders Aged 35-50

\begin{tabular}{lccrrrrr} 
Aged 15-30 & \multicolumn{7}{c}{ Number of Lags Included } \\
& 0 & 1 & 2 & 3 & 4 & 5 & 6 \\
\hline Not Intensely & -0.028 & -0.098 & $-0.182^{*}$ & $-0.178+$ & -0.167 & $-0.218+$ & -0.214 \\
Violent Games & $(0.046)$ & $(0.061)$ & $(0.092)$ & $(0.100)$ & $(0.115)$ & $(0.117)$ & $(0.134)$ \\
Intensely & -0.012 & -0.043 & $-0.079 *$ & $-0.081+$ & $-0.077+$ & $-0.093 *$ & $-0.093+$ \\
Violent Games & $(0.019)$ & $(0.026)$ & $(0.039)$ & $(0.042)$ & $(0.046)$ & $(0.047)$ & $(0.054)$ \\
\hline $\begin{array}{l}\text { Chi-Sq test of } \\
\text { difference }\end{array}$ & \multirow{2}{*}{0.32} & 2.31 & $3.56+$ & 2.62 & 1.66 & $3.04+$ & 2.18 \\
\hline
\end{tabular}

Aged 35-50

Number of Lags Included

\begin{tabular}{lccccccc} 
& 0 & 1 & 2 & 3 & 4 & 5 & 6 \\
\hline Not Intensely & -0.020 & -0.089 & $-0.236^{*}$ & $-0.210+$ & -0.214 & $-0.243+$ & -0.235 \\
Violent Games & $(0.049)$ & $(0.068)$ & $(0.112)$ & $(0.117)$ & $(0.136)$ & $(0.138)$ & $(0.157)$ \\
Intensely & -0.014 & -0.042 & $-0.103^{*}$ & $-0.096^{*}$ & $-0.098+$ & $-0.105+$ & -0.102 \\
Violent Games & $(0.021)$ & $(0.029)$ & $(0.047)$ & $(0.049)$ & $(0.055)$ & $(0.056)$ & $(0.062)$ \\
\hline $\begin{array}{l}\text { Chi-Sq test of } \\
\text { difference }\end{array}$ & 0.05 & 1.37 & $4.01^{*}$ & 2.63 & 1.99 & 2.69 & 1.91
\end{tabular}

For both the top and bottom panels, each column represents results from a separate instrumental variables regression. Each row reports the sum of coefficients for a variable for different possible lag lengths. Not reported are coefficients of month dummies and a time trend. Absolute value of $z$-statistics in parentheses. + significant at $10 \% ; *$ significant at $5 \% ; * *$ significant at $1 \%$ 
Table 8

The Effect of Video Games on the Fraction of Crimes that are Violent

By Offenders Aged 15-30 versus Offenders Aged 35-50

\begin{tabular}{lccccccc} 
Aged 15-30 & \multicolumn{7}{c}{ Number of Lags Included } \\
& 0 & 1 & 2 & 3 & 4 & 5 & 6 \\
\hline Not Intensely & $-0.034+$ & $-0.057 *$ & $-0.090^{*}$ & $-0.087 *$ & $-0.100^{*}$ & $-0.087+$ & -0.059 \\
Violent Games & $(0.019)$ & $(0.025)$ & $(0.038)$ & $(0.040)$ & $(0.048)$ & $(0.051)$ & $(0.057)$ \\
Intensely & -0.010 & $-0.018+$ & $-0.031+$ & $-0.029+$ & $-0.034+$ & -0.028 & -0.017 \\
Violent Games & $(0.008)$ & $(0.011)$ & $(0.016)$ & $(0.017)$ & $(0.019)$ & $(0.021)$ & $(0.022)$ \\
\hline $\begin{array}{l}\text { Chi-Sq test of } \\
\text { difference }\end{array}$ & \multirow{2}{*}{$4.32 *$} & $6.42^{*}$ & $6.84 * *$ & $5.61 *$ & $5.11 *$ & $3.54+$ & 1.40 \\
\hline
\end{tabular}

\begin{tabular}{|c|c|c|c|c|c|c|c|}
\hline \multirow[t]{2}{*}{ Aged 35-50 } & \multicolumn{7}{|c|}{ Number of Lags Included } \\
\hline & 0 & 1 & 2 & 3 & 4 & 5 & 6 \\
\hline Not Intensely & -0.023 & -0.021 & -0.028 & -0.011 & 0.005 & 0.020 & 0.046 \\
\hline Violent Games & $(0.016)$ & $(0.020)$ & $(0.028)$ & $(0.033)$ & $(0.040)$ & $(0.043)$ & $(0.048)$ \\
\hline Intensely & -0.008 & -0.006 & -0.009 & -0.002 & 0.003 & 0.009 & 0.019 \\
\hline Violent Games & $(0.007)$ & $(0.009)$ & $(0.012)$ & $(0.014)$ & $(0.016)$ & $(0.017)$ & $(0.019)$ \\
\hline $\begin{array}{l}\text { Chi-Sq test of } \\
\text { difference }\end{array}$ & 1.94 & 1.42 & 1.24 & 0.20 & 0.00 & 0.17 & 0.84 \\
\hline
\end{tabular}


Table 9

The Aggregate Effect of Video Games on both Violent and Non-Violent Crimes

By Crimes Located at Schools and Not at Schools

\begin{tabular}{lccccccc} 
Crimes on & \multicolumn{7}{c}{ Number of Lags Included } \\
Campus & 0 & 1 & 2 & 3 & 4 & 5 & 6 \\
\hline Not Intensely & -0.050 & -0.442 & $-0.841^{*}$ & $-1.135^{*}$ & $-1.108+$ & $-1.396^{*}$ & -0.976 \\
Violent Games & $(0.265)$ & $(0.307)$ & $(0.415)$ & $(0.484)$ & $(0.567)$ & $(0.595)$ & $(0.724)$ \\
Intensely & 0.016 & -0.177 & $-0.342^{*}$ & $-0.468^{*}$ & $-0.461^{*}$ & $-0.563^{*}$ & -0.399 \\
Violent Games & $(0.112)$ & $(0.132)$ & $(0.175)$ & $(0.202)$ & $(0.230)$ & $(0.240)$ & $(0.289)$ \\
\hline $\begin{array}{l}\text { Chi-Sq test of } \\
\text { difference }\end{array}$ & \multirow{2}{*}{0.16} & 2.06 & $4.07 *$ & $5.24 *$ & $3.50+$ & $5.24 *$ & 1.70 \\
\hline
\end{tabular}

\begin{tabular}{|c|c|c|c|c|c|c|c|}
\hline \multirow{2}{*}{$\begin{array}{l}\text { Crimes off } \\
\text { Campus }\end{array}$} & \multicolumn{7}{|c|}{ Number of Lags Included } \\
\hline & 0 & 1 & 2 & 3 & 4 & 5 & 6 \\
\hline Not Intensely & -0.024 & -0.086 & $-0.189 *$ & $-0.185+$ & -0.171 & $-0.221+$ & -0.207 \\
\hline Violent Games & $(0.045)$ & $(0.061)$ & $(0.094)$ & $(0.103)$ & $(0.120)$ & $(0.121)$ & $(0.137)$ \\
\hline Intensely & -0.008 & -0.035 & $-0.078^{*}$ & $-0.080+$ & -0.075 & $-0.090+$ & -0.087 \\
\hline Violent Games & $(0.019)$ & $(0.026)$ & $(0.040)$ & $(0.043)$ & $(0.048)$ & $(0.049)$ & $(0.055)$ \\
\hline $\begin{array}{l}\text { Chi-Sq test of } \\
\text { difference }\end{array}$ & 0.31 & 2.00 & $3.87 *$ & $2.87+$ & 1.73 & $3.13+$ & 2.06 \\
\hline \multicolumn{8}{|c|}{$\begin{array}{l}\text { For both the top and bottom panels, each column represents results from a separate instrumental variables } \\
\text { regression. Each row reports the sum of coefficients for a variable for different possible lag lengths. Not } \\
\text { reported are coefficients of month dummies and a time trend. Absolute value of } \mathrm{z} \text {-statistics in parentheses. + } \\
\text { significant at } 10 \% ; * \text { significant at } 5 \% ; * * \text { significant at } 1 \%\end{array}$} \\
\hline
\end{tabular}


Table 10

The Effect of Video Games on the Fraction of Crimes that are Violent

By Crimes Located at Schools and Not at Schools

Crimes on

Campus

Number of Lags Included

\begin{tabular}{lccccccc} 
& 0 & 1 & 2 & 3 & 4 & 5 & 6 \\
\hline Not Intensely & 0.086 & 0.057 & 0.077 & 0.072 & 0.141 & 0.111 & 0.165 \\
Violent Games & $(0.057)$ & $(0.070)$ & $(0.098)$ & $(0.104)$ & $(0.123)$ & $(0.132)$ & $(0.158)$ \\
Intensely & 0.020 & 0.002 & 0.012 & 0.009 & 0.034 & 0.026 & 0.049 \\
Violent Games & $(0.024)$ & $(0.030)$ & $(0.042)$ & $(0.043)$ & $(0.050)$ & $(0.053)$ & $(0.063)$ \\
\hline $\begin{array}{l}\text { Chi-Sq test of } \\
\text { difference }\end{array}$ & $3.54+$ & 1.65 & 1.23 & 1.02 & 2.03 & 1.12 & 1.43 \\
\hline
\end{tabular}

Crimes off

Campus

Number of Lags Included

\begin{tabular}{lccccccc} 
& 0 & 1 & 2 & 3 & 4 & 5 & 6 \\
\hline Not Intensely & $-0.037+$ & $-0.047+$ & $-0.061+$ & -0.030 & -0.024 & -0.000 & 0.007 \\
Violent Games & $(0.020)$ & $(0.026)$ & $(0.037)$ & $(0.042)$ & $(0.048)$ & $(0.054)$ & $(0.061)$ \\
Intensely & $-0.016+$ & $-0.020+$ & -0.025 & -0.013 & -0.011 & -0.002 & 0.001 \\
Violent Games & $(0.009)$ & $(0.011)$ & $(0.015)$ & $(0.017)$ & $(0.020)$ & $(0.022)$ & $(0.025)$ \\
\hline $\begin{array}{l}\text { Chi-Sq test of } \\
\text { difference }\end{array}$ & 2.58 & $3.06+$ & 2.68 & 0.46 & 0.19 & 0.00 & 0.02
\end{tabular}

For both the top and bottom panels, each column represents results from a separate instrumental variables regression. Each row reports the sum of coefficients for a variable for different possible lag lengths. Not reported are coefficients of month dummies and a time trend. Absolute value of $\mathrm{z}$-statistics in parentheses. + significant at $10 \% ; *$ significant at $5 \% ; * *$ significant at $1 \%$ 